Location

$665-3390$

Paisothone

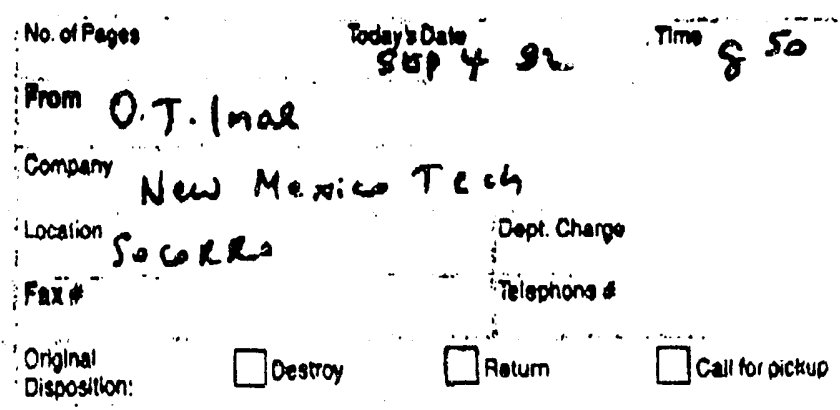

$i$

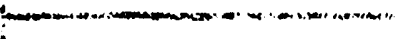

LA-SUB- $-93-11 / 1$

DE93 008676

\title{
REPORT ON THE SINTERING AND PROPERTIES OF MgO and MgO-5qTiC
}

\author{
Furat BENGISU and Osman $T$. INAL \\ New Mexico Institute of Mining and Technology \\ Socorro, NM 87801
}

July 1992

\section{DISCLAIMER}

This remort was prepared as an account of work sponsored by an agency of the United States Government. Neither the United States Government nor any agency thereof, nor any of their employees, makes any warranty, express or implied, or assumes anv legal liability or responsibility for the accuracy, completeness, or usefulness of any information, apparatus, product, or process disclosed, or represents that its use would not infringe privately owned rights. Reference herein to any specific commercial prutuct, process, or service by trade name, trademark, manufacturer, or otherwise does not necessarily constitute or imply its endorsement, recommendation, or favoring by the United States Government or any agency thereof. The views and opinion $f$ authors expressed herein do not necessarily state or reflect those of the United States Government or any agency thereof.

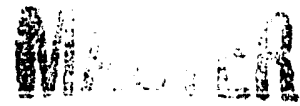




\section{IATRODUCTIOR}

Mgo is a ceramic material with many potential applications owing to its high melting point $\left(2620^{\circ} \mathrm{C}^{1}\right)$, high resistivity $\left(>10^{16}\right.$ 1), and good corrosion resistance ${ }^{2}$. Mgo has only one structure type at all temperatures up to the melting point. Above $1600^{\circ} \mathrm{C}$ it is completely ductile, which can also be used to advantage. Another very important advantage regarding $\mathrm{MgO}$ is its affordability and availability. There are vast, well-distributed resources of magnesite in the world and there are even more abundant resources of dolomite which are cheaper to obtain than magnesite. Mgo is also extracted directly from sea water ${ }^{2}$.

The main disadvantage of this material is its low fracture toughness $\left(2-3 \mathrm{MPam}^{1 / 23}\right.$ ) and strength (flexural strength about 100 MPa '). Limited effort has been devoted on the development of Mgo based composites so far. Ikuma et al. ${ }^{3}$ incorporated $\mathrm{ZrO}_{2}$ particles into a Mgo matrix, resulting in toughness values of $3.7 \mathrm{MPam}^{1 / 2}$. Nilhara ' developed nanophase composites including Mgo-sic with fracture toughness and strength values $2-4$ times that of Mgo alone. Tamar1 'produced hot pressed Mgo-sic composites and achieved a fracture toughness of about $5 \mathrm{MPam}^{1 / 2}$ with 30 volt sic. Higher strength values were also reported for composites with 30-50 vol sic particles.

The present study attempts to 11luminate some of the untouched areas with regard to rapid rate sintering of $\mathrm{MgO}$ and Mgo-TiC composites, as well as to the resultant mechanical properties. 


\section{IXPIRIYUETAI}

II.1. Preconsolidation Processing

The starting materials were $99.5 \%$ pure Mgo" (MgOp), technical grade $\mathrm{MgO}^{*}$ ( $\mathrm{MgO}_{\mathrm{TG}}$ ) containing $98 \% \mathrm{MgO}, 0.8 \% \mathrm{CaO}, 0.35 \% \mathrm{SiO}_{2}, 0.2 \%$ $\mathrm{Fe}_{2} \mathrm{O}_{3}, 0.158 \mathrm{Al}_{2} \mathrm{O}_{3}$, and 0.47 other 1mpurities, and $99.5 \%$ pure $\mathrm{TiC}$ ". Average Fisher particle sizes given by the manufacturers were 0.28 $\mu \mathrm{m}, 5.00 \mu \mathrm{m}$, and $1.56 \mu \mathrm{m}$, respectively. Mgo-5volitic (MgO-5TiC) mixtures were prepared by ball milling in methanol for 5 hours. Mixed slurries were partially dried on a hot plate while stirring. Further drying was achieved in a furnace at $100-2000^{\circ} \mathrm{C}$ for $10-15$ min. This method prevented segregation of the different phases. Drled cakes were crushed and ground using an alumina pestle and mortar. The powders were screened using a 175 mesh sieve. Mgo-5Tic powders prepared with the above method as well as $\mathrm{MgO}_{\mathrm{p}}$ and $\mathrm{MgO}_{\mathrm{TO}}$ powders were dry pressed at $19 \mathrm{MPa}$. Graphite foil was used to prevent sticking of pure Mgo-containing powders to the top and bottow of the steel mold during cole pressing.

slips of each composition were prepared for slip casting by mechanical stirring of the constituents at high speed using a 3 speed household mixer. Since Mgo reacts with water, alcohol is recommended for 1ts slip casting ${ }^{6}$. Ethanol was used with Mgo while methanol was found to provide better dispersion of $\mathrm{MgO}_{\mathrm{Tg}}$. In the case of $\mathrm{MgO}_{\mathrm{p}}$ and $\mathrm{MgO}_{\mathrm{p}}-5 \mathrm{TiC}$ powders, a solid-to-liquid ratio of $80 \mathrm{z}$ was used. On the other hand, a solid-to-liquid ratio of 1508 was poseible in the case of $\mathrm{KgO}_{\mathrm{TG}}$ and $\mathrm{MgO}_{\mathrm{TG}}-5 \mathrm{TIC}$ powders, probably due to the larger particle size, and thus, a smaller surface area that needed to be wet. Preliminary experiments with slip casting of alcohol-based slurries indicated that cracking occurs due to high drying ratec. Therefore, drying rates were reduced by covering

* M-1017, Cerac, Inc., Milwaukee, WI

** - MagChem 35, Martin Marietta Specialties, Inc., Hunt Valley, MD $\star \star \star-T-1227$. Cerac, Inc., M11waukee, WI 
the molds. This allowed drying of 30 ma dlameter by 10 mm thick samples in about 36 hours. Slow drying totally eliminated the cracking problem.

Both cold pressed and slip cast Mgo-containing bodies had lower green densities compared to $\mathrm{MgO}_{\mathrm{TG}}$-containing bodies; $29 \%$ theoretical density (TD) vs 32-358TD in the case of cold pressed samples and $20 \%$ vs $25 \%$ TD in the case of slip cast samples.

Rods $6 \mathrm{~mm}$ in diameter and $20 \mathrm{~mm}$ in length were prepared for plasma sintering experiments. W filaments were inserted from one end of these rods.

\section{II.2. Bintering}

\section{II.2.1. Conventional sintering}

For conventional sintering studies, slip cast and cold pressed discs were put on alumina plates. The sintering schedule consisted of a 2-3 h heat-up regime, a $4 \mathrm{~h}$ hold time at $1600^{\circ} \mathrm{C}$, and furnace cooling. All samples were sintered in air.

\section{II.2.2. Plasma sintering}

Rods were suspended from one end via $w$-filaments along the central axis of two concentric steel cylinders. Plasma sintering was carried out using the hollow-cathode discharge (HCD) assembly depicted in Fig.1. Upon reaching a 300 mTorr vacuum, the plasma is generated by applying a 600-700 V DC voltage between the anode and cathode. Samples at the center of the cylinders (anode and cathode) are heated by atom bombardment and the hot plasma. The sample temperature was measured by an infrared pyrometer" sintering was conducted in air plasmas at $1200-1300^{\circ} \mathrm{C}$, which was the highest temperature attainable in the system. Two samples per composition were sintered with a hold time of 4 minutes at the peak temperature. 


\section{II.2.3. Mlerowave Blntering}

A $2.45 \mathrm{GHz}$ microwave source was used for sintering. Each sample was individually sintered in low density $\mathrm{ZrO}_{2}$ insulation in air. sample temperatures were measured using a fiber optic thermometer ". Sintering was done at $1500-1600^{\circ} \mathrm{C}$ for 5 minutes in air.

\section{III, RESULTB}

III.1. 8intering of KgO and MgO-5FiC

The consolidation behavior was analyzed by comparing the relative density of each sample after completion of sintering runs. Table $I$ shows the final relative densities achieved by three different sintering methods. Relative densities of plasma-sintered samples are very low due to the low sintering temperatures and relatively slow sintering kinetics of Mgo. Microwave-sintered samples attained higher relative densities compared to plasmasintered samples, but lower densities than those obtained by conventional sintering. The lower relative densities of microwavesintered materials are possibly due to the much shorter sintering times compared to conventional sintering $(5 \mathrm{~min}$ vs $240 \mathrm{~min}$, respectively). In the case of Mgo-Tic composites, low bulk densities were achieved by microwave processing. The reason for low densities is the intarnal porosity caused by a gaseous reaction product. The pores formed apongy structure in the composites and resulted in low relative densitles. However, the exterior of the samples sintered to much bigher density probably due to easier exit of the gaseous reaction product. $x$-ray analysis of the composite indicated that $\mathrm{Mg}_{2} \mathrm{TiO}_{4}$ formed during sintering of all MgOTiC composites. This suggests that the gaseous reaction product was $\mathrm{CO}$ or $\mathrm{CO}_{2}$.

The results illustrated in Table I indicate that $\mathrm{MgO}_{\mathrm{Te}}$ and $\mathrm{MgO}_{\mathrm{ro}}-5 \mathrm{TIC}$ samples are easier to sinter than $\mathrm{MgO}_{\mathrm{p}}$ and $\mathrm{MgO}_{\mathrm{P}}-5 \mathrm{TIC}$

- Accutiber Model 100, Multichannel optical Fiber Thermometer, Acculiber, Inc., Beverton, OR 
samples. The reason for improved sinterablilty of Mgo $_{\text {TG }}$-based samples is probably a higher contribution of liguid phase sintering to overall consolidation, due to the presence of impuxities such as $\mathrm{SiO}_{2}, \mathrm{Fe}_{2} \mathrm{O}_{3}$, and $\mathrm{Al}_{2} \mathrm{O}_{3}$. Liquid phase sintering has previously been shown to improve the sintering of $\mathrm{MgO}^{7}$.

comparison of the relative densities of conventionally sintered samples in Table $I$ indicates that MgO-5TiC composites attained higher relative densities than did monolithio Mgo. This is an interesting result since second phase particles are generally known to decrease the sinterability of a parent matexial, such as in the case of TiC, SiC, or $\mathrm{B}_{4} \mathrm{C}$ particles in $\mathrm{Al}_{2} \mathrm{O}_{3}$. In fact, plasma sintering results also show that Tic limits the sinterability of Mgo when sintering is done in vacuum, where $T 1 C$ does not react with Mgo. Table I shows that the addition of 5 volt TiC limited the sinterability of Mgo significantly in all cases. Hence, these results suggest that $\mathrm{TiC}$ (or $\mathrm{TI}$, since $\mathrm{C}$ is lost by the reaction) acts as a sintering aid in Mgo when sintering is done in air. One possibility that comes into mind is liquid phase sintering by the phase $\mathrm{Mg}_{2} \mathrm{TiO}_{4}$. However, this phase has a melting point of $1740^{\circ} \mathrm{C}^{\circ}$ and since the highest sintering temperature was $1600^{\circ} \mathrm{C}$, liquid phase sintering due to the new phase does not apply to the present case.

Comparison of the intered relative densities of., islip cast and cold pressed samples of same composition show that pressed samples reached to higher fractional densities than slip cast samples. This difference is most likely due to the higher green densities of cold pressed samples. It is generally accepted that higher powder compact densities lead to higher sintered densities. Higher particle packing densities and smaller average pore sizes lead to a higher average curvature in the neck regions between particles. Therefore, the average driving force for sintering is higher ${ }^{10}$.

overall, the results suggest that rapid rate, short-term sintering does not bear any advantage over conventional sintering since kgo powders, unlike, for example, $\mathrm{Al}_{2} \mathrm{O}_{3}{ }^{11}$, have sluggish ointering kinetics. 


\section{Irr.2. Miorostruature}

Microstructures of fracture surfaces are shown in figs.2 through 7. In general, these micrographs support our discussion given in the previous section. Comparison of fig.2(a) and (b) indicates that the porosity in pressed and sintered $\mathrm{MgO}_{\mathrm{TG}}$ decreased significantly by the addition of 5 volitic. A similar result is found in the case of slip cast and cold pressed plus sintered Mgo (Figs.3 and 4). It is also seen that grain growth accompanies decreased porosity.

Another important observation from fracture surfaces is the change in fracture modes. In the case of monolithic Mgo, the fracture mode is predominantly intergranulax, as seen in figs.2(a), $3(a)$, and $4(a)$. On the other hand, in the case of Mgo-Tic composites, a significant portion of fracture occurred in the transgranular mode, as suggested by faceted grains in figs.2(b), $3(b)$, and $4(b)$. Even in the composites with considerable porosity this behavior is evident. The change of the fracture mode from intergranular to transgranular may be due to the increased grain size as suggested elsewhere 12 .

Figures 5 and 6 show the microstructures of microwave sintered samples. Microwave sintered $\mathrm{MgO}_{\mathrm{p}}$ has a fine grain size (about $3 \mathrm{~mm}$ ) and little porosity (Fig.5(a)). The average partlcle size of microwave sintered $\mathrm{O}_{\mathrm{ie}}$ la larger than thut of wgo, fabout $7 \mu \mathrm{m}$ grain size). Thts diffurence is probaby do to the higher sintering tempexature used for these samples $\left(1600^{\circ} \mathrm{C}\right.$ vs $1500^{\circ} \mathrm{C}$, respectively). The interfor of $\mathrm{KgO}_{\mathrm{p}}-5 \mathrm{TIC}$ composite has a spongy structure caused by the gaseous reaction of Mgo and Tic. This structure is show. in tig.5(b). The microstructure of microwave sintered $\mathrm{MgO}_{\mathrm{TO}}-5 \mathrm{TiC}$ is signiflcantly coarser than that of $\mathrm{MgO}_{\mathrm{TG}}$ (roughly $15 \mu \mathrm{m}$ grain alze).

Although the bulk of plasma sintered Mgo had a low relative density, its exterior was sintered to quite high densities as suggested by the micrograph shown in Fig.7. The average grain size is very small $(1-2 \mu \mathrm{m})$ indicating that no grain growth occurred during the short term, low temperature sintering. This suggests 
that longer sintering times may produce higher densitios by the plasma sintering process.

\section{III.3. Mechanical Eroperties}

The mechanical properties of monolithic Mgo and Mgo-5Tic composites fabricated by vaxious techniques are shown in Table II. overall, hardness values improved with increasing relative densities, as expected. For example, the hardness of $\mathrm{Mgo}_{\mathrm{p}}$ increased from 1.3 to $3.4 \mathrm{GPa}$ when its relative density was increased from $78.8 \%$ to $87.7 \%$ TD by the application of cold pressing instead of slip casting. Similarly, the hardness of $\mathrm{MgO}_{\mathrm{p}}-5 \mathrm{TiC}$ was raised from 2.1 to $4.0 \mathrm{GPa}$ with a density increase from 81.38 to 91.78 . The average hardness of $\mathrm{MgO}_{p}$ increased from 3.4 to $4.0 \mathrm{GPa}$ and that of $\mathrm{MgO}_{\text {IG }}$ increased from 2.6 to $4.0 \mathrm{GPa}$ with the addition of 5 volf $\mathrm{TiC}$. This increase may be explained by the improvement in the fractional densities.

The hardness of microwave-sintered $\mathrm{MgO}_{\mathrm{IG}}-5 \mathrm{TiC}$ is quite high when its relative density is taken into account. This discrepancy is due to the fact that the tabulated density comes from the bulk sample. The hardness values were determined from the outer region which had a much higher relative density than the sponge-Iike interior.

The fracture toughness of Ho wac raised by Tic additions in the case of conventionally sintered samples, which were the only samples where a useful number of tests was possible. The fracture toughness of slip cast and sintered $\mathrm{MgO}_{\mathrm{p}}$ remained essentially constant but that of $\mathrm{MgO}_{\mathrm{Ta}}$ increased $2 x$ m 2.1 to $2.7 \mathrm{MPam}^{1 / 2}$ with TiC additions (Table II). Similarly, the fracture toughness of pressed and sintered $\mathrm{MgO}_{\mathrm{Te}}$ increased from 2.2 to $2.9 \mathrm{MPam}^{1 / 2}$ with 5 vol TiC addition.

These result show that the mechanical properties of Mgo can be improved by small additions of TiC. Additions of larger amounts of TiC to $\mathrm{MgO}(50$ vol\$) resulted in extreme reaction and porosity in an air-sintered sample. Therefore, high amounts of Tic additions to kgo are not advisable. 
IV. CO\&CLOBTONB

The following conclusions have been found from the present study: 1) sintering of technical grade Mgo yields higher fractional densities compared to research grade (relatively pure) Mgo sintered under the sare conditions. The higher densities can be attributed to a larger contribution of liquid phase sintering in the former powder, where a high fraction of liquid phase formers are present. 2) Tic reacts with Mgo when sintering of MgO-TiC composites is employed in air. This reaction yields $\mathrm{Mg}_{2} \mathrm{TiO}_{4}$ and $\mathrm{CO}$ or $\mathrm{CO}_{2}$ gas. The gaseous reaction products produce macropores during rapid heating (microwave sintering) or when the amount of $\mathrm{TiC}$ is high (e.g. 50voli) during conventional sintering.

3) The reaction between $M g O$ and $T i C$ can be suppressed in vacuum according to plasma sintering results. This indlcates that the reaction between $\mathrm{MgO}$ and $\mathrm{TiC}$ is promoted by air sintering.

4) Plasma sintering of Mgo at relatively low temperatures $\left(1300^{\circ} \mathrm{C}\right.$ ) and short times does not produce satisfactory results. TiC particles decrease the sinterability of Mgo during vacuum (plasma) sintering.

5) 5 vols TiC additions increase the sinterability of Mgo during conventional air sintering. The mechanism of this improvement is not clear. Larger ( 50 volz) additions decrease sinterabllity due to severe reaction leading to macropores formed by the gaseous reaction product.

6) Kicrowave sintering of Mgo has been shown to be possible by Indirect microwave heating for the first time to the authors' best knowledge. The sintering conditions need to be further optimized for maximum densification.

7) The mechanical properties of Kgo have been improved by the addition of small amounts of Tic to the starting powders. This improvement is probably due to increased fractional densitics.

V. sUGCLETIOAS FOR JUTUR: 8TODX

In order to prevent unwanted reactions, second phase partlcies compatible with Mgo should be carefully selected. Data in MgO-net 1 
nitride, carbide, and boride systems are very $11 \mathrm{mited}$ but valuable. Such systems should be systematically studied to understand their chemical, physical, and mechanical behavior. second phase additions should be oxidation resistant if the composite is considered for high temperature applications in oxidizing atmospheres.

The reaction of TiC and Mgo can be supressed by vacuum consolidation according to the present study. Hot pressing in vauum or inert atmosphere might be an ideal way of producing kigo-TiC composites and analyze their mechanical properties.

Microwave sintering of Mgo should also be studied further. Emphasis should be given to increasing the sintering temperatures and times which may impiove the sintered densities. An interesting study would be the microwave sintering of ${\mathrm{MgO}-\mathrm{ZrO}_{2}}$ composites, since $\mathrm{ZrO}_{2}$ is more easily coupled with microwaves 13 and the composite has been shown to have good mechanical properties ${ }^{3}$.

\section{RETEREMCES}

1. D.W.Richerson, Modern Ceramic Engineering, Marcel Dekker, Inc., NX (1982)

2. I.J.McColm, Ceramic Saience tor Matertal Technoleaists, Leonard Hill, London, England (1983)

3. Y.Ikuma, W.Komatsu, and S.Yaegashi, " $\mathrm{ZrO}_{2}$-Toughened $\mathrm{MgO}$ and critical Factors in Toughening Ceramic Materials by Incorporating $\mathrm{ZrO}_{2}$ ", J.Mater.Sci.Lett., 4 (1985) 63-66

4. K.Niihara, "Nanostructure Design and Mechanical Propertles of Ceramic Composites", J.Jpn.Soc.Pow.Metall., 37 (2] 348-51 (1990)

5. N.Tamari, "Sintering of Mgo-sic Composite Ceramics and Thetr Properties", J.Ceram.Soc.Jpn., 97 [1] 79-84 (1989)

6. E.Richerson and D.w.Rykewitch, Oxtde Ceramics, Academic Press. Inc., Orlando, FL (1985)

7. W.D.Ringery, E.Niki, and K.D.Narasimhan, "Sintering of Oxide and Carbide-Metal Compositions in the Presence of a Liquid Phase". J.Av.Ceram.Soc., 44 [1] 29-35 (1961)

8. M.Bengisu and O.T.Inal, "Rapidly sintered Particulate ceras: : 
Meltrix Composites", Ceram.Int., 17 [3] 187-98 (1991)

9. Phase Diagrams for Ceramists, edited by M.K.Reser, the American Ceramic Society, Inc., Westerville, OH (1964), p.112

10. T.S.Xeh and M.D.Sacks, "Effect of Green Microstructure on sintering of Alumina", in Ceramic Transactions Vol.7, edited b/ C.A.Handwarker, J.E.Blendell, and W.Kaysser, the American Ceramic Society, Inc., Westerville, OH (1990), pp.309-31

31. J.D.Katz and R.D.Blake, "Mlcrowave sintering of Multiple Alumina and Composite Components", Am.Ceram.Soc.Bul1,, 70 [8] 130408 (1991)

12. R.W.Rice, "Ceramic Fracture Features, Observations, Mechanisms, and Uses", in Fractography of ceramic and Metal Failures, ASTM STP 827, edited by J.J.Mecholsky, Jr., and S.R.Powell, Jr., Am.Soc.Test.Mater., Fhiladelphla, PA (1984), pp.5-103

13. M.A.Janney, C.L.Calhoun, and H.D.Kimrey, "Microwave Sinterins of Solid oxide Fuel Cell Materials: I, Zirconia-8 mol yttria", J.Am.ceram.Soc., 75 [2] 341-46 (1992) 
Table I. Fractional Densities of $\mathrm{MgO}$ and $\mathrm{MgO}-5 \mathrm{TiC}$ Fabricated by Different Methods

\begin{tabular}{|c|c|c|}
\hline $\begin{array}{l}\text { Fabrication } \\
\text { Method }\end{array}$ & Material & $\begin{array}{c}\text { \% Theoretical } \\
\text { Density }\end{array}$ \\
\hline \multirow{4}{*}{$\begin{array}{l}\text { plasma sintering/ } \\
1300^{\circ} \mathrm{C} / 4 \mathrm{~min} / \\
\text { vacuum }\end{array}$} & $\mathrm{MgO}_{\mathrm{p}}$ & 65.6 \\
\hline & $\mathrm{MgO}_{\mathrm{p}}-5 \mathrm{TiC}$ & 41.8 \\
\hline & $\mathrm{MgO}_{\mathrm{TG}}$ & 69.8 \\
\hline & $\mathrm{MgO}_{\mathrm{TG}}-5$ & 48.0 \\
\hline \multirow{4}{*}{$\begin{array}{l}\text { slip casting/ } \\
\text { conventional sintering/ } \\
1600^{\circ} \mathrm{C} / 240 \mathrm{~min} / \text { air }\end{array}$} & $\mathrm{MgO}_{\mathrm{p}}$ & 78.8 \\
\hline & $\mathrm{MgO}_{\mathrm{p}}-5 \mathrm{TiC}$ & 81.3 \\
\hline & $\mathrm{MgO}_{\mathrm{TG}}$ & 87.5 \\
\hline & $\mathrm{MgO}_{\mathrm{TO}}-5 \mathrm{TiC}$ & 90.7 \\
\hline \multirow{4}{*}{$\begin{array}{l}\text { cold pressing/ } \\
\text { conventional sintering } \\
1600^{\circ} \mathrm{C} / 240 \mathrm{~min} / \text { air }\end{array}$} & $\mathrm{MgO}_{\mathrm{p}}$ & 87.7 \\
\hline & $\mathrm{MgO}_{\mathrm{p}}-5 \mathrm{TiC}$ & 91.7 \\
\hline & $\mathrm{MgO}_{\mathrm{TG}}$ & 86.2 \\
\hline & $\mathrm{MgO}_{\mathrm{TO}}-5 \mathrm{TiC}$ & 92.5 \\
\hline \multirow{4}{*}{$\begin{array}{l}\text { cold pressing/ } \\
\text { ricrowave sintering/ } \\
1500-1600^{\circ} \mathrm{C} / 5 \mathrm{~min} / \text { air }\end{array}$} & $\mathrm{MgO}_{\mathrm{p}}$ & 77.4 \\
\hline & $\mathrm{MgO}_{\mathrm{p}}-5 \mathrm{TiC}$ & 71.8 \\
\hline & $\mathrm{MgO}_{\mathrm{TG}}$ & 84.0 \\
\hline & $\mathrm{MgO}_{\mathrm{TO}}-5 \mathrm{TiC}$ & 77.3 \\
\hline
\end{tabular}


Table II. Mechanical Properties of MgO and $\mathrm{MgO}-5 \mathrm{TiC}$ Fabricated by Different Methods

\begin{tabular}{|c|c|c|c|c|c|}
\hline $\begin{array}{l}\text { Fabrication } \\
\text { Method }\end{array}$ & Material & $\begin{array}{c}\text { \% Theoretical } \\
\text { Density }\end{array}$ & $\begin{array}{c}\text { HV } \\
\text { (GPa) }\end{array}$ & $\begin{array}{c}\mathrm{K}_{\mathrm{Ie}} \\
\left(\mathrm{MPa} \mathrm{m}^{1 / 2}\right)\end{array}$ & $\begin{array}{l}\text { Number } \\
\text { of } \\
\text { Samples }\end{array}$ \\
\hline \multirow{4}{*}{$\begin{array}{l}\text { plasma sintering } / \\
1300^{\circ} \mathrm{C} / 4 \text { min/ } \\
\text { vacuum }\end{array}$} & $\mathrm{MgO}_{\mathrm{p}}$ & 65.6 & $\mathbf{N} / \mathbf{A}$ & $N / A$ & $N, / A$ \\
\hline & $\mathrm{MgO}_{\mathrm{p}}-5 \mathrm{TiC}$ & 41.8 & 0.3 & $\mathbf{N} / \mathbf{A}$ & $N / A$ \\
\hline & $\mathrm{MgO}_{\mathrm{TG}}$ & 69.8 & 2.3 & N/A & $N / A$ \\
\hline & $\mathrm{MgO}_{\mathrm{TG}}-5 \mathrm{TiC}$ & $48 . C$ & 1.0 & N/A & N/A \\
\hline \multirow{4}{*}{$\begin{array}{l}\text { casting/ } \\
\text { conventional sintering/ } \\
1600^{\circ} \mathrm{C} / 240 \mathrm{~min} / \text { air }\end{array}$} & $\mathrm{MgO}_{\mathrm{p}}$ & 78.8 & 1.3 & 2.3 & 3 \\
\hline & $\mathrm{MgO}_{\mathrm{p}}-5 \mathrm{TiC}$ & 81.3 & 2.1 & 2.1 & 3 \\
\hline & $\mathrm{MgO}_{\mathrm{TG}}$ & 87.5 & 2.1 & 2.1 & 7 \\
\hline & $\mathrm{MgO}_{\mathrm{TG}}-5 \mathrm{TiC}$ & 90.7 & 2.9 & 2.7 & 6 \\
\hline \multirow{4}{*}{$\begin{array}{l}\text { cold pressing/ } \\
\text { conventional sintering/ } \\
1600^{\circ} \mathrm{C} / 240 \mathrm{~min} / \text { air }\end{array}$} & $\mathrm{MgO}_{p}$ & 87.7 & 3.4 & $N / A$ & N/A \\
\hline & $\mathrm{MgO}_{\mathrm{p}}-5 \mathrm{TiC}$ & 91.7 & 4.0 & 2.6 & 2 \\
\hline & $\mathrm{MgO}_{\mathrm{TG}}$ & 86.2 & 2.6 & 2.2 & 6 \\
\hline & $\mathrm{MgOTO}_{\mathrm{TO}}-\mathrm{TiC}$ & 92.5 & 4.0 & 2.9 & 4 \\
\hline \multirow{3}{*}{$\begin{array}{l}\text { cold pressing/ } \\
\text { microwave sintering/ } \\
1500-1600^{\circ} \mathrm{C} / 5 \mathrm{~min} / \text { air }\end{array}$} & $\mathrm{MgO}_{\mathrm{p}}$ & 77.4 & 1.5 & 1.2 & 4 \\
\hline & $\mathrm{MgO}_{\mathrm{p}}-5 \mathrm{TiC}$ & 71.8 & 2.3 & $\mathbf{N} / \mathbf{A}$ & N/A \\
\hline & $\mathrm{MgO}_{\mathrm{TG}}$ & 84.0 & 2.2 & 2.0 & 4 \\
\hline . & $\mathrm{MgO}_{\mathrm{TG}}-5 \mathrm{TiC}$ & 77.3 & 3.2 & 1.7 & 1 \\
\hline
\end{tabular}




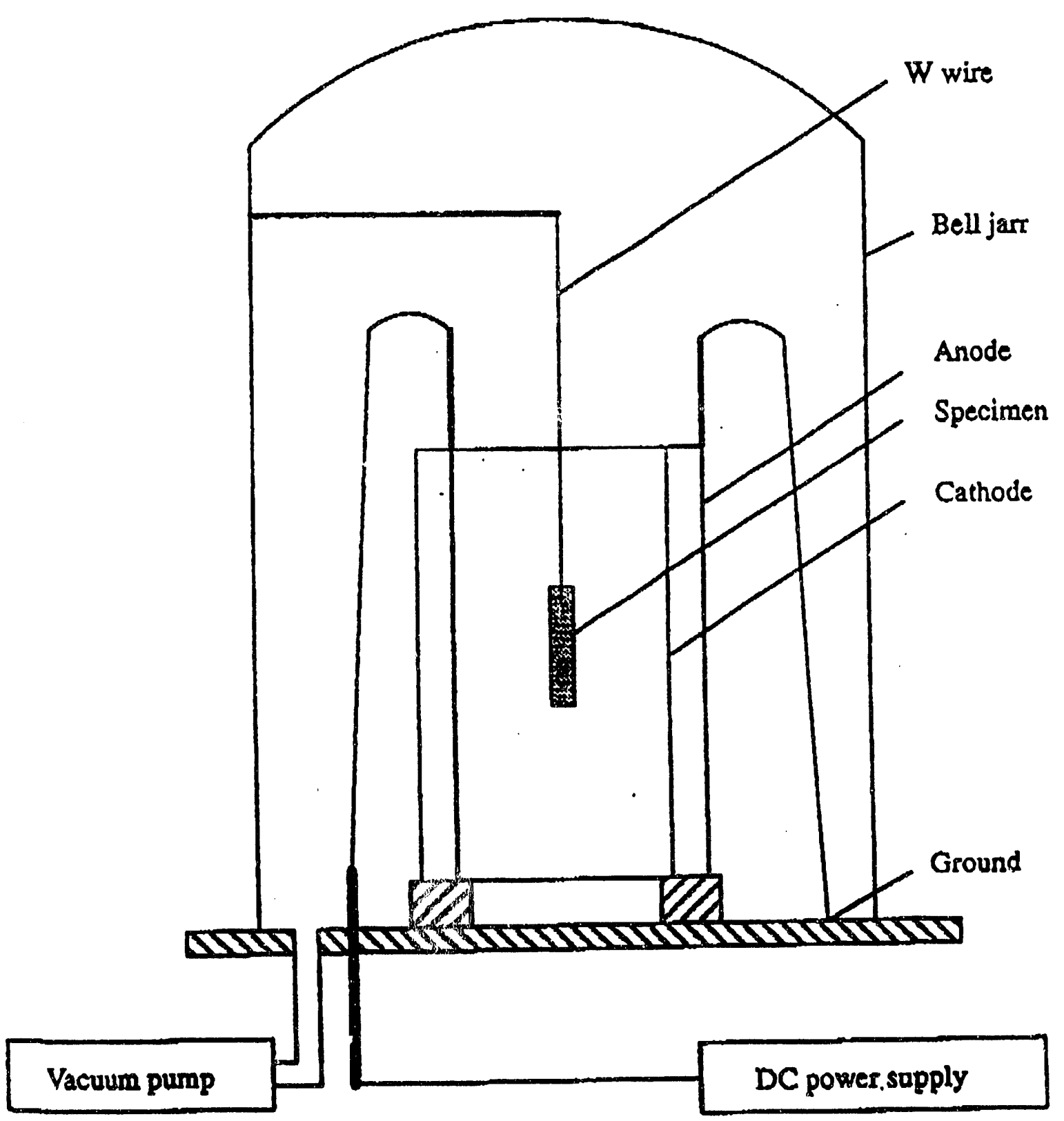



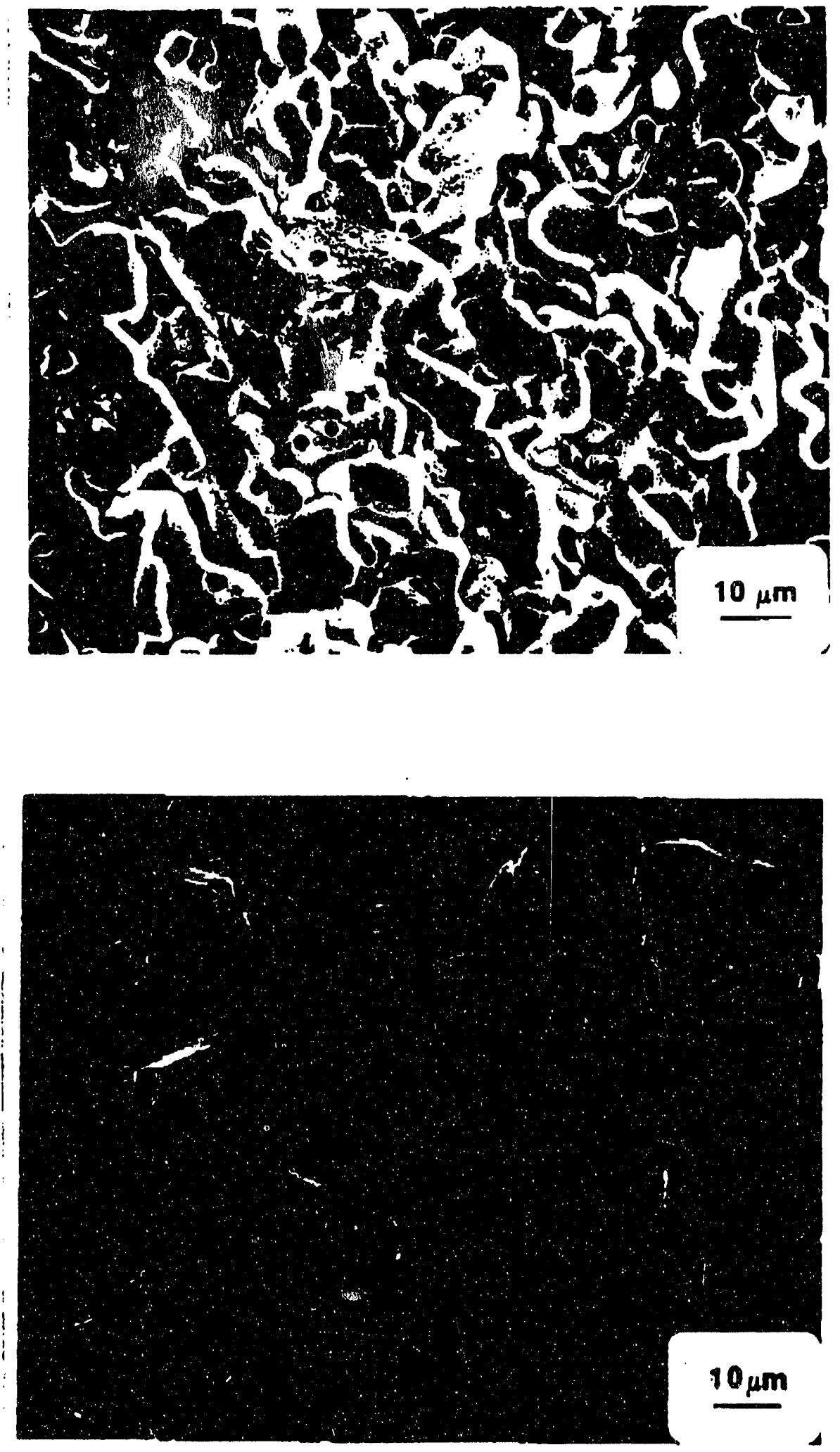

Fig.2. SEY micrograph of pressed and sintered a) $\mathrm{MgO}_{\mathrm{Tg}}$ and 

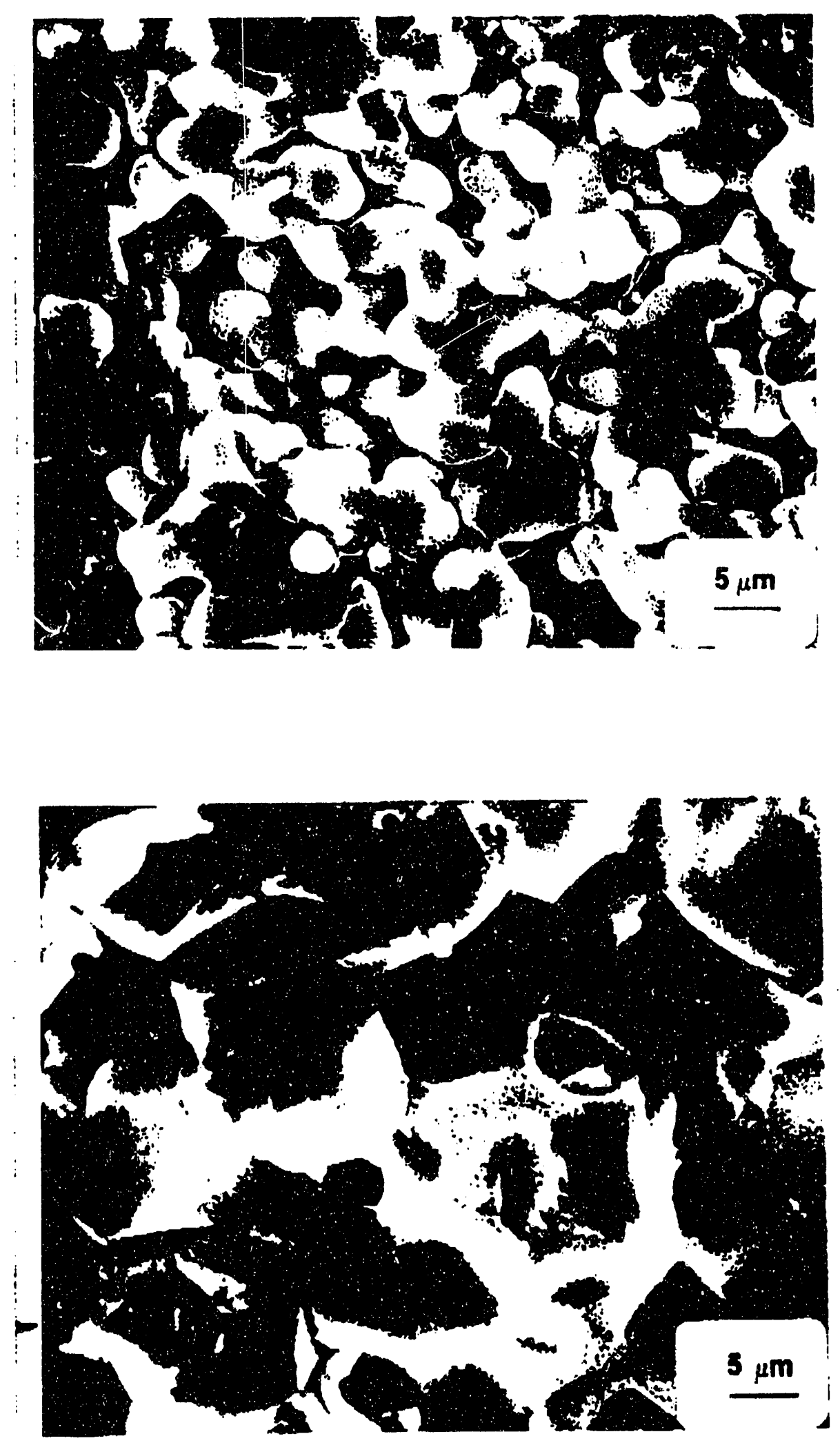

F1g.3. SEM micrograph of $\mathbf{3 l i p - c a s t ~ a n d ~ s i n t e r e d ~ a ) ~ M g O ~ a n d ~}$ 

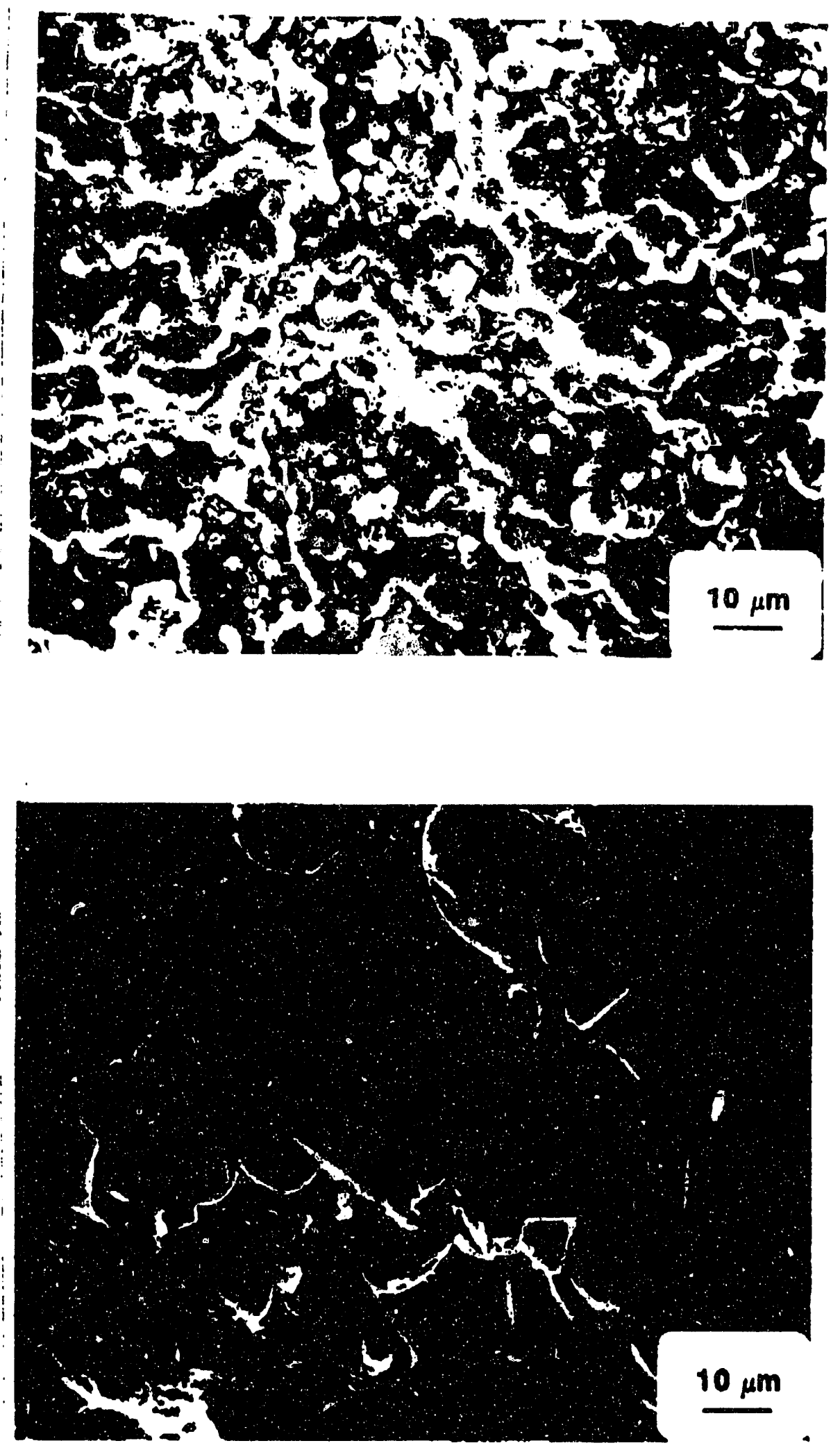

FIg.4. SEM micrograph of pressed and sintered a) $\mathrm{MgO}_{\mathrm{p}}$ and 

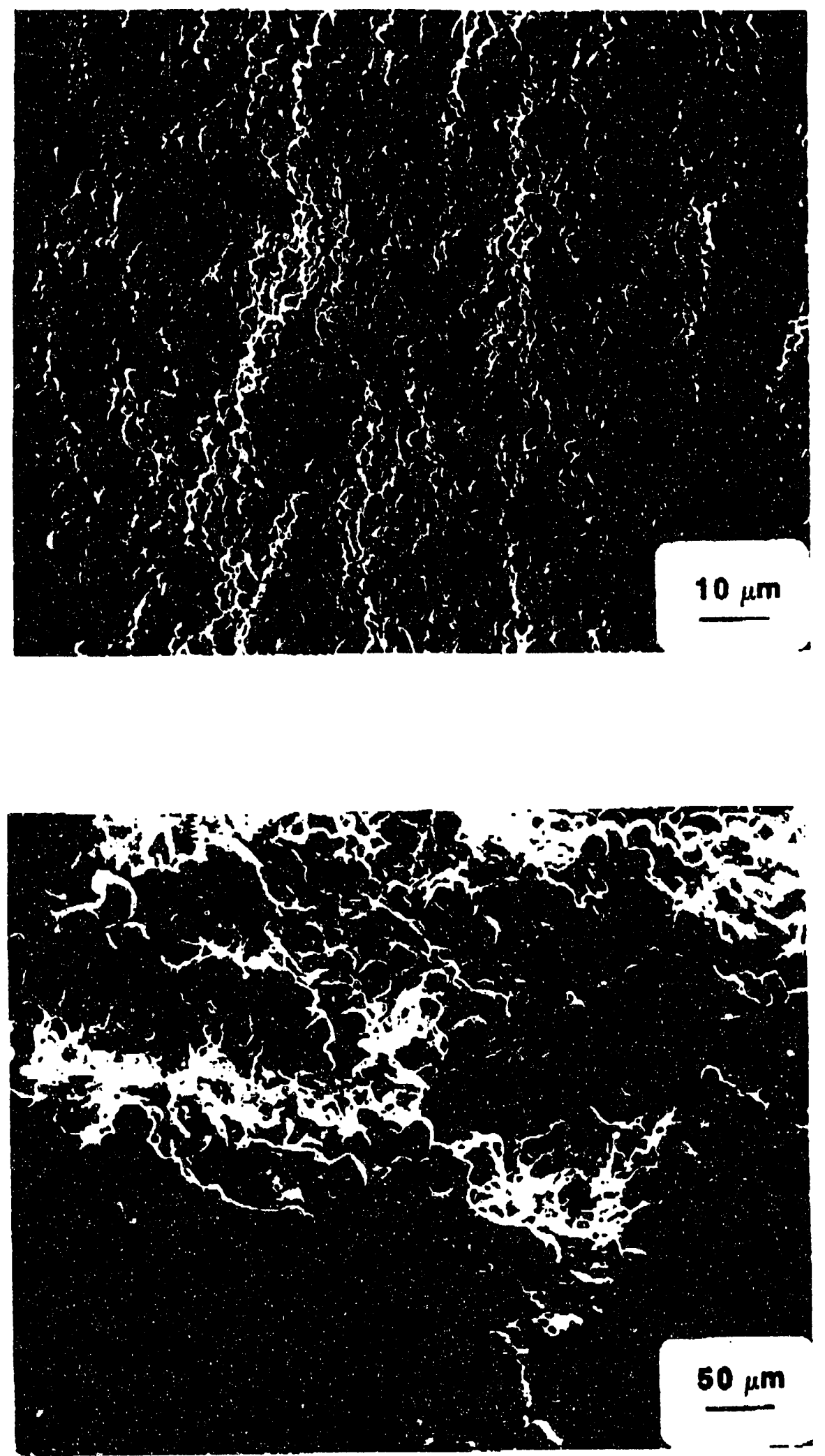

Fig.5. SEM micrograph of microwave sintered a) $\mathrm{MgO}_{\mathrm{p}}$ and 

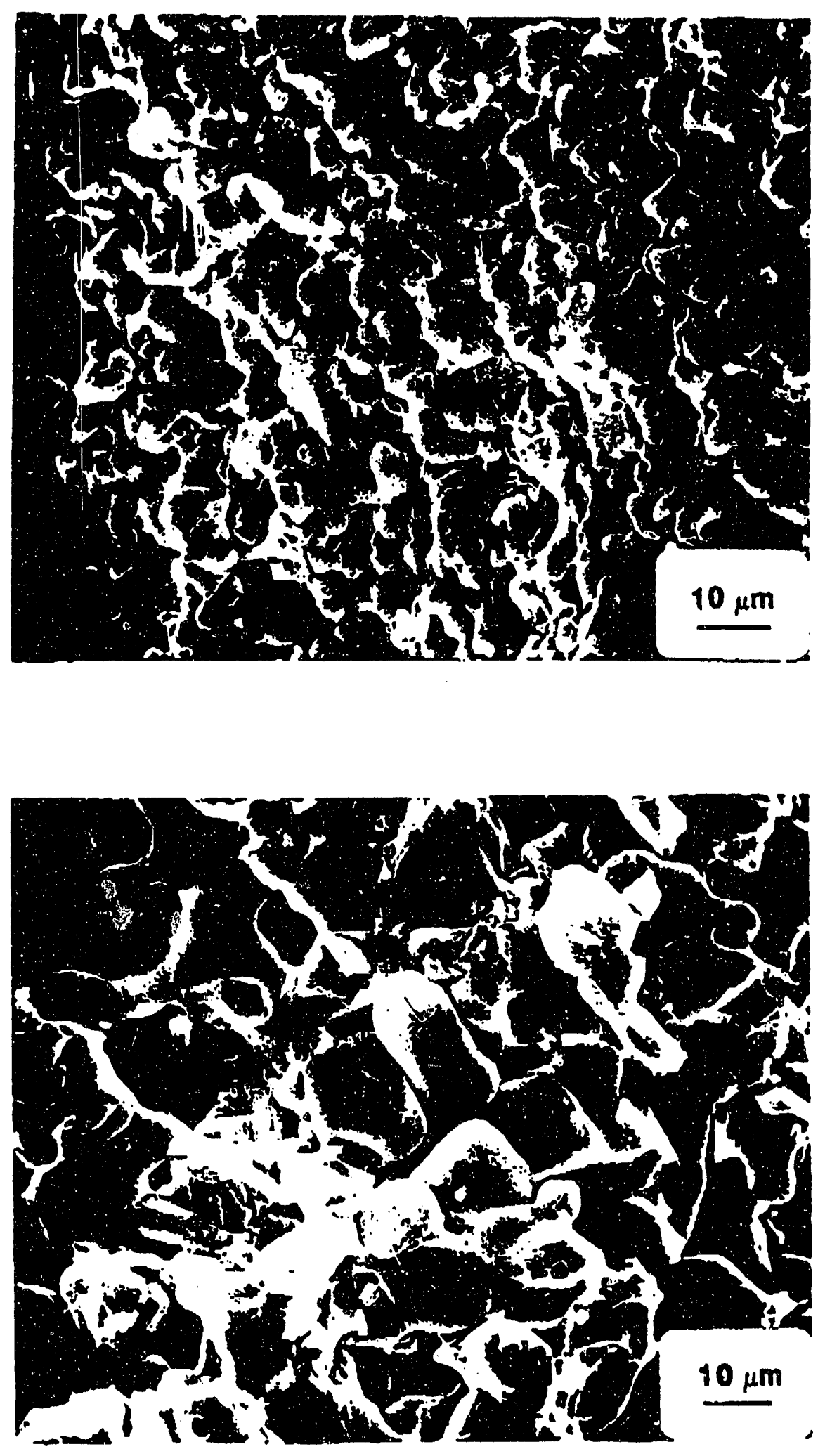

Fig:6. SEM micrograph of mierowave sintered a) MgO 


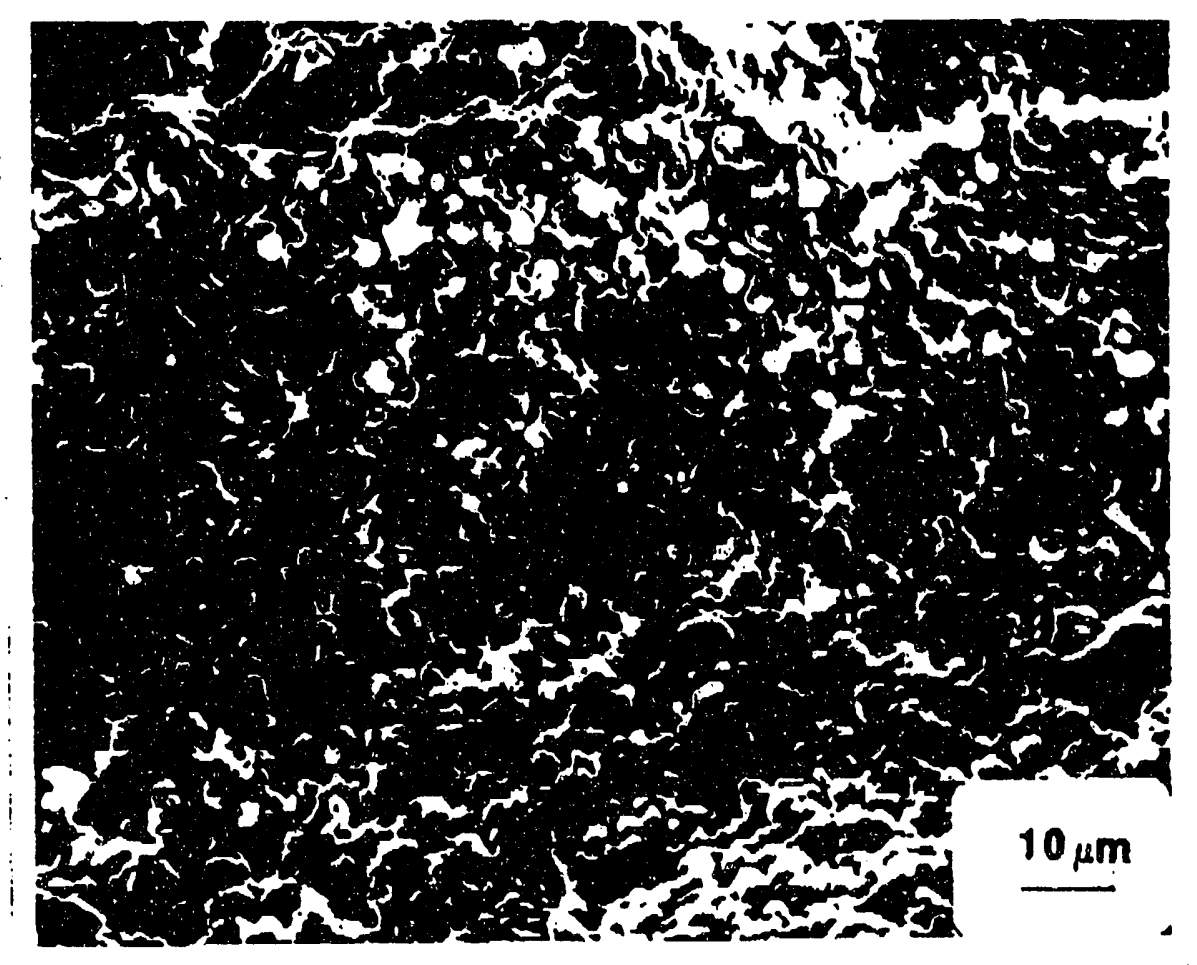

F1g.7. SEM micrograph of plasma sintered MgO 
The following equipment are required for Euture work on the sintering and properties of Mgo and Mgo-TiC,

- DTA and control panel: To analyze the reaction(s) between Mgo and TiC

- Dilatometer: To study the sintering kinetics of Mgo and MgoTic compacts

- Lindberg furnace: To sinter Mgo and Mgo-TiC ceramics -Clausing lathe: To shape green and sintered ceramic bodies

- Control panel for hydraulic press: To control the necessary cold-pressing parameters during static powder compaction. 

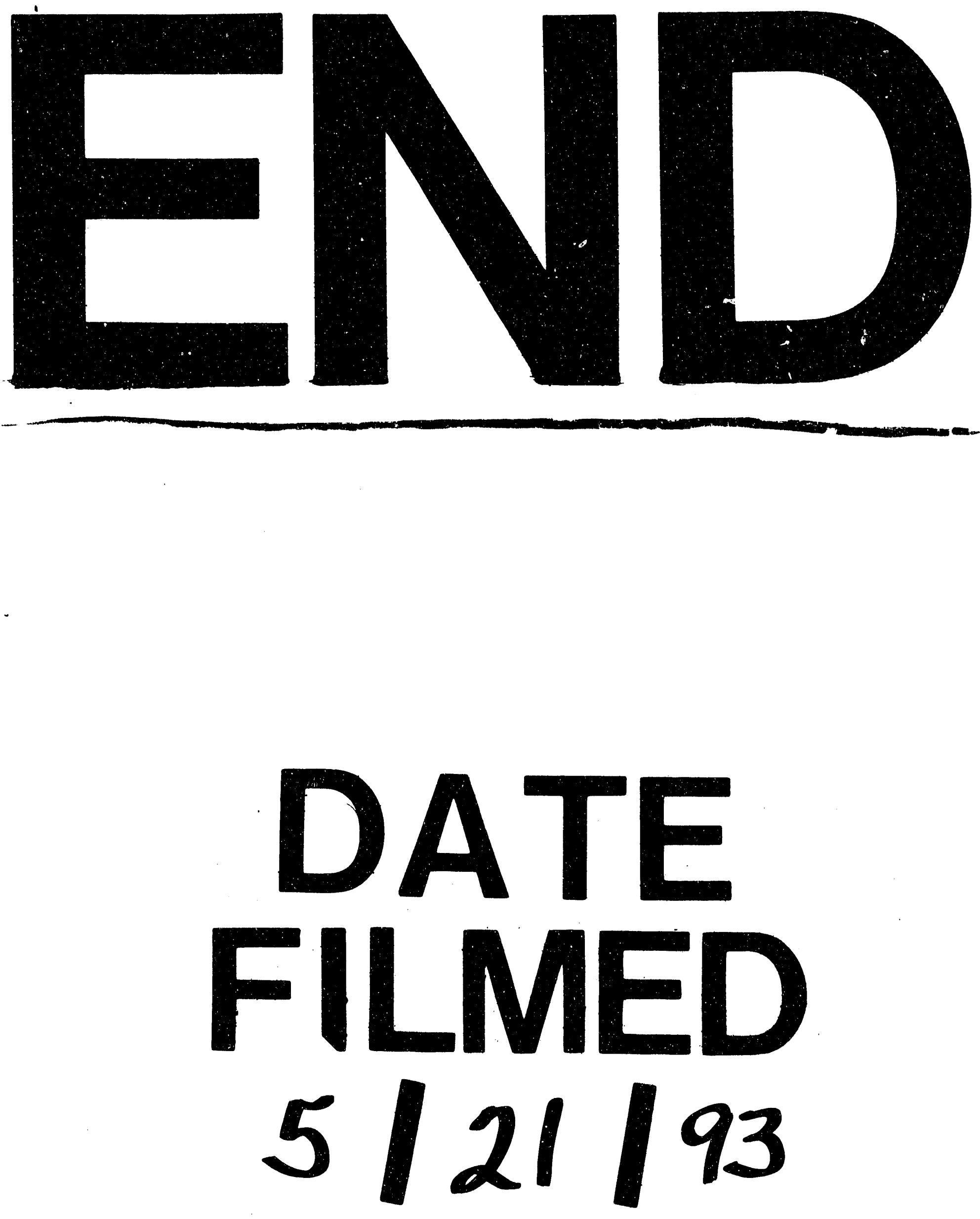
